\title{
Substitusi Abu Ampas Tebu dan Abu Sekam Padi pada Semen terhadap Kuat Tarik Belah Beton Mutu Tinggi di Lingkungan Berbeda
}

\author{
Balqis Pratami Sartono ${ }^{1}$ Mochammad Afiffuddin ${ }^{2}$ Huzaim $^{3}$ \\ ${ }^{1}$ Mahasiswa, Jurusan Teknik Sipil,Universitas Syiah Kuala, Banda Aceh 23111, Indonesia \\ ${ }^{2,3}$ Jurusan Teknik Sipil,Universitas Syiah Kuala, Banda Aceh 23111, Indonesia \\ Email: balqissartono@yahoo.co.id
}

\begin{abstract}
The raw materials of cement is decreased due to ongoing exploitation. Further research is needed to find the latest alternative sources as a viable cement substitution. Bagasse ash and rice husk ash containts enough silica to be used as cement substitution material. This study would determine the effect substitution of bagasse ash and rice husk ash on protected, unprotected, and buried environmental conditions on the splitting tensile strength of high strength concrete. This study uses substitution variations of $0 \%, 2.5 \%$, 5\%, and $7.5 \%$ of the volume of cement, taken from a combination of a mixture of $25 \%$ bagasse ash and $75 \%$ rice husk ash. This study uses K-600 with 0.3 Water-cemen $t$ ratio. The results showed the greatest value of splitting tensile strength occurred in high strength concrete happened at the $2.5 \%$ both at 7 and 28 days treatment, especially after the specimens were placed in a different environment for 28 days ie $12.07 \%$ in a protected environment, $16.06 \%$ in an unprotected environment, and $14.74 \%$ in the buried environment.
\end{abstract}

Keywords: Bagasse Ash, Rice Husk Ash, Different Environments, Tensile Strenght, High Strenght Concrete

\section{Abstrak}

Bahan baku semen semakin tergerus akibat eksploitasi yang terus dilakukan, sehingga dibutuhkan penelitian untuk mengetahui bahan substitusi semen yang layak. Abu ampas tebu dan abu sekam padi memiliki kandungan silika yang cukup untuk digunakan sebagai bahan subsitusi semen. Tujuan penelitian ini adalah untuk mengetahui pengaruh substitusi abu ampas tebu dan abu sekam padi pada kuat tarik belah beton mutu tinggi pada kondisi lingkungan terlindung, tidak terlindung, dan tertimbun tanah terhadap kuat tarik belah beton mutu tinggi. Penelitian ini menggunakan variasi substitusi $0 \%, 2,5 \%$, 5\%, dan 7,5\% dari volume semen, diambil dari kombinasi campuran $25 \%$ abu ampas tebu dan $75 \%$ abu sekam padi, menggunakan K-600 FAS 0,3. Hasil penelitian menunjukkan kenaikan nilai kuat tarik belah terbesar terjadi pada beton mutu tinggi dengan persentase 2,5\%, khususnya setelah benda uji diletakkan di lingkungan berbeda selama 28 hari, yaitu 12,07\% pada lingkungan terlindung, 16,06\% di lingkungan tidak terlindung, dan 14,74\% di lingkungan tertimbun.

Kata kunci : Abu Sekam Padi, Abu Ampas Tebu, Lingkungan Berbeda, Kuat Tarik Belah, Beton Mutu Tinggi

\section{Pendahuluan}

Kebutuhan akan fasilitas infrastruktur yang semakin maju mengakibatkan berkembangnya berbagai inovasi beton, salah satunya beton mutu tinggi yang memerlukan semen dalam jumlah yang banyak. Beton mutu tinggi yang pada hakikatnya mencakup kekuatan, ketahanan, dan masa layan yang baik semakin banyak digunakan untuk pembangunan konstruksi di berbagai keadaan lingkungan. Bersamaan dengan meningkatnya kebutuhan akan beton mutu tinggi, kebutuhan akan semen juga meningkat. Peningkatan kebutuhan semen mengakibatkan bahan baku semen semakin tergerus dan berkurang akibat eksploitasi yang terus dilakukan, untuk itu diperlukan penelitian untuk mencari tahu bahan substitusi semen yang layak.

Ampas tebu dan sekam padi merupakan salah satu sumber limbah terbanyak yang terdapat di Aceh. Abu ampas tebu dan abu sekam padi mengandung bahanbahan yang pembentuk pozzolan, sehingga cocok sebagai bahan substitusi semen. Pemanfaatan campuran abu ampas tebu dan sekam padi sebagai subsitusi semen untuk pencampuran beton memerlukan analisis kesesuaian, salah satunya dengan menganalisis nilai kekuatan (strength) serta daya tahan (durability). Durabilitas (ketahanan) adalah sifat dasar beton, yaitu mampu untuk mempertahankan bentuknya dari berbagai kondisi lingkungan tanpa cacat selama umur pelayanannya. Kondisi lingkungan perawatan tergantung dari beberapa keadaan lingkungan.

Pelaksanaan penelitian dilakukan di Laboraturium Konstruksi dan Bahan Bangunan Fakultas Teknik Universitas Syiah Kuala. Benda uji yang digunakan adalah silinder, dengan jumlah substitusi semen terdapat 4 varian, yaitu $0 \%, 2,5 \%, 5 \%$, dan 7,5\% dari volume semen. Penelitian ini menggunakan $25 \%$ abu ampas tebu dan $75 \%$ abu sekam padi, karena abu sekam padi mengandung senyawa silika lebih banyak dari abu ampas tebu, yang akan mengurangi sensitifitas beton terhadap agresi sulfat, Dharma[1]. Jumlah benda uji untuk masing-masing variabel adalah 3 buah dengan ukuran $15 \mathrm{~cm}$ x $30 \mathrm{~cm}$, diletakkan pada tiga lingkungan berbeda dengan total yang digunakan berjumlah 72 buah, menggunakan K-600 dengan faktor air semen (FAS) 0,3. Benda uji direndam selama 28 hari di bak perendaman, kemudian diletakkan dilingkungan terlindung, tidak terlindung, dan tertimbun, baru kemudian dilakukan pengujian kuat tarik belah. Total waktu yang digunakan untuk penelitian ini adalah 56 hari.

Penelitian ini bertujuan untuk mengetahui pengaruh substitusi kombinasi $25 \%$ abu ampas tebu dan $75 \%$ abu sekam padi pada kondisi lingkungan terlindung, tidak 
terlindung, dan tertimbun tanah terhadap kuat tarik belah beton mutu tinggi.

\section{Tinjauan Kepustakaan}

\subsection{Beton Mutu Tinggi}

Beton mutu tinggi adalah beton yang memiliki FAS rendah dan memiliki kekuatan tekan 40-80 MPa.

\subsection{Semen}

Semen adalah bubuk halus sebagai bahan pengikat yang diperoleh dengan klinker. Bubuk halus ini bila dicampur dengan air akan menjadi keras dan digunakan sebagai bahan hidrolis, Hernando[2].

Spesifikasi semen mencakup 5 jenis, ASTM C 15007[3], diantaranya:

1. Tipe I, digunakan untuk umum;

2. Tipe II, digunakan untuk yang tahan terhadap sulfat sedang atau panas hidrasi sedang;

3. Tipe III, digunakan untuk yang memerlukan kekuatan awal tinggi;

4. Tipe IV, digunakan untuk yang memerlukan panas hidrasi rendah dengan kekuatan awal rendah;

5. Tipe $\mathrm{V}$, digunakan untuk yang tahan terhadap kadar sulfat tinggi.

Semen mengandung 20,60\% $\mathrm{SiO}_{2}, 3,30 \% \quad \mathrm{Fe}_{2} \mathrm{O}_{3}$, $4,40 \% \mathrm{Al}_{2} \mathrm{O}_{3}$, dan $62,90 \% \mathrm{CaO}$.

\subsection{Abu Ampas Tebu}

Abu ampas tebu adalah hasil pembakaran ampas tebu dari proses pembakaran. Pembakaran abu ampas tebu akan menghasilkan senyawa silika $\left(\mathrm{SiO}_{2}\right)$ sehingga bisa digunakan untuk bahan pengganti semen, Maulana[4]. Abu ampas tebu mengandung 42,47\% $\mathrm{SiO}_{2}$, $1,69 \% \mathrm{Fe}_{2} \mathrm{O}_{3}, 1,02 \% \mathrm{Al}_{2} \mathrm{O}_{3}$, dan $5,01 \% \mathrm{CaO}$.

\subsection{Abu Sekam Padi}

Abu sekam padi adalah limbah yang diperoleh dari hasil pembakaran sekam padi. Abu Sekam padi mengandung $65,70 \% \mathrm{SiO}_{2}, 0,08 \% \mathrm{Fe}_{2} \mathrm{O}_{3}, 0,02 \% \mathrm{Al}_{2} \mathrm{O}_{3}$, dan $1,49 \% \mathrm{CaO}$, sehingga cocok digunakan sebagai bahan substitusi semen.

\subsection{Sifat-sifat Fisis Agregat}

Pemeriksaan sifat fisis dilakukan untuk menentukan bahwa agregat yang digunakan memenuhi syarat sebagai bahan pembentuk beton. Pemeriksaan sifat fisis menggunakan metode American Society for Testing and Material (ASTM).

\subsection{Kuat Tarik Belah Beton}

Pengujian kuat tarik belah beton dilakukan berdasarkan standar ASTM C 496M-04[5], menggunakan benda uji silinder beton yang diletakkan pada arah memanjang diatas alat penguji kemudian beban tekan diberikan merata arah tegak dari atas pada seluruh panjang silinder. Tegangan tarik yang timbul sewaktu benda uji terbelah disebut sebagai split cylinder strength, diperhitungkan sebagai berikut:

$$
f_{t}=\frac{2 . P}{\pi L \cdot D} \text {. }
$$

keterangan :

$$
\begin{aligned}
& f t=\text { kuat tarik belah }\left(\mathrm{N} / \mathrm{mm}^{2}\right) \\
& P=\text { beban pada waktu belah }(\mathrm{N}) \\
& L=\text { Panjang benda uji silinder }(\mathrm{mm}) \\
& D=\text { diameter benda uji silinder }(\mathrm{mm})
\end{aligned}
$$

\subsection{Lingkungan Perawatan Beton}

Lingkungan beton didasarkan pada kondisi lapangan, di mana beton terkondisikan sesuai dengan tuntutan struktur maupun lingkungannya. Menurut Rayyana[6], beberapa lingkungan beton adalah sebagai berikut:

1. Lingkugan terlindung dengan pendekatan lingkungan bangunan seperti terowongan, subway, dan lain-lain;

2. Lingkungan tidak terlindung dengan pendektatan lingkungan bangunan seperti gedung, menara, struktur atas jembatan, jalan raya, dan lain-lain;

3. Lingkungan perendaman tidak terlindung dengan pendekatan lingkungan seperti bendungan, kolam renang dan lain-lain;

4. Lingkungan perendaman air tawar/perawatan standar ASTM.

\subsection{Analisa Varian}

Menurut Hines dan Montgomery[7], analisis varian dilakukan untuk menentukan kesimpulan dari hasil variabel-variabel pengujian. Untuk menganalisa pengaruh suatu faktor/variabel bebas yang diteliti terhadap suatu besaran terikat variabel yang dipengaruhinya digunakan analisis varian klasifikasi dua

\begin{tabular}{|c|c|c|c|c|}
\hline $\begin{array}{l}\text { Sumber } \\
\text { Varian }\end{array}$ & $\begin{array}{l}\text { Jumlah } \\
\text { Kuadrat }\end{array}$ & $\begin{array}{c}\text { Derajat } \\
\text { Kebebasan }\end{array}$ & Rata-rata kuadrat & Fo \\
\hline A perlakuan & $S S_{A}$ & $a-1$ & $M S_{A}=\frac{S S_{A}}{a-1}$ & $f o=\frac{M S_{A}}{M S_{E}}$ \\
\hline B perlakuan & $S S_{B}$ & $b-1$ & $M S_{B}=\frac{S S_{B}}{b-1}$ & $f o=\frac{M S_{B}}{M S_{E}}$ \\
\hline Interaksi & $S S_{A B}$ & $(a-1)(b-1)$ & $\begin{array}{l}M S_{A B} \\
=\frac{S S_{A B}}{(a-1)(b-1)}\end{array}$ & $f o=\frac{M S_{A B}}{M S_{E}}$ \\
\hline Error & $S S_{E}$ & $a b(n-1)$ & $M S_{E}=\frac{S S_{E}}{a b(n-1)}$ & \\
\hline
\end{tabular}
arah model efek tetap seperti yang diperlihatkan pada Tabel 1 berikut

Tabel 1 Analisis Varian Klasifikasi Dua Arah Model Tetap

Sumber[7]

Dimana :

$$
\begin{aligned}
& S S_{A}=\sum_{i=1}^{a} \frac{y_{i}^{2}}{b n}-\frac{y_{\ldots}^{2}}{a b n} \\
& S S_{B}=\sum_{i=1}^{b} \frac{y_{j}^{2}}{a n}-\frac{y_{\ldots}^{2}}{a b n} \\
& S S_{A B}=\sum_{i=1}^{a} \sum_{j=1}^{b} \frac{y_{j}^{2}}{b n}-\frac{y_{\ldots}^{2}}{a b n}-S S_{A}-S S_{B,} \text { 5) }
\end{aligned}
$$




$$
\begin{aligned}
S S_{A B} & =\sum_{i=1}^{a} \sum_{j=1}^{b} \sum_{k=1}^{n} y_{i j k}^{2}-\frac{y_{\ldots}^{2}}{a b n}, \ldots \ldots \ldots \ldots \ldots . . \\
S S_{E} & =S S_{T}-S S_{A B}-S S_{A}-S S_{B},
\end{aligned}
$$

Keterangan :

$a=$ jumlah variasi faktor $\mathrm{a}$;

$b=$ jumlah variasi faktor $\mathrm{b}$;

$n$ = jumlah pengulangan benda uji;

$a b n=$ jumlah keseluruhan benda uji.

\section{Metode Penelitian}

Metodologi penelitian merupakan penjabaran secara rinci dan sistematis tentang tahapan dalam penelitian.

\subsection{Persiapan Material dan Peralatan yang digunakan}

Material yang digunakan dalam penelitian ini adalah semen Portland, agregat halus, agregat kasar, air, superplasticizer, abu ampas tebu dan abu sekam padi dengan variasi $0 \%, 2,5 \%, 5 \%$, dan $7,5 \%$ dari volume semen, dengan komposisi pencampuran $25 \%$ abu ampas tebu dan $75 \%$ abu sekam padi untuk masing-masing variasi. Semen yang digunakan berasal dari PT. Semen Andalas Indonesia.

Agregat halus yang digunakan agregat yang lolos saringan 2,36 mm (No.8) berasal dari Krueng Aceh dan agregat kasar atau batu pecah yang digunakan batu pecah yang lolos saringan 9,5 mm yang didatangkan dari pabrik stone crusher PT. Lhoknga Beton.

Abu ampas tebu diambil dari proses pembakaran ampas tebu yang menjadi bahan bakar boiler di Kilang Tebu, Blang Mancung, Aceh Tengah.

Abu sekam padi diambil dari sisa proses pembakaran sekam padi di Kilang Padi, Lam Ateuk, Aceh Besar.

Superplastisticizer, bahan kimia tambahan yang digunakan adalah jenis Sika Viscocrete-10 dari PT. Sika Indonesia sebesar $1,5 \%$ dari berat semen.

Peralatan yang digunakan antara lain adalah oven, timbangan, satu set saringan, gelas kaca ukur berbagai ukuran, sekop, tongkat besi, mesin pengaduk beton (concrete mixer) berkapasitas 90 liter, kerucut Abraham's, palu karet, geobak sorong, cetakan silinder diamter $15 \mathrm{~cm}$ x $30 \mathrm{~cm}$, dan mesin uji kuat tekan beton (hydraulic pressure gauge).

\subsection{Pemeriksaan Material}

Pemeriksaan terhadap agregat kasar dan agregat halus dilakukan di Laboraturium Konstruksi dan Bahan Bangunan Fakultas Teknik Universitas Syiah Kuala. Pemeriksaan yang dilakukan pada agregat kasar dan halus adalah berat jenis (specific gravity), penyerapan (absorption), berat volume (bulk density), dan analisa saringan (sieve analysis).

\subsection{Pembuatan Benda Uji}

Langkah-langkah yang dilakukan dalam pembuatan dan perawatan benda uji adalah sebagai berikut :

1. Menyiapkan material dan peralatan benda uji (beton);

2. Dilakukan pemeriksaan sifat fisis pada agregat.
3. Merencanakan campuran beton (mix design). Menimbang bahan yang dibutuhkan sesuai dengan yang telah ditentukan dalam perencanaan;

4. Mengaduk mortar beton mutu tinggi ke dalam mixer dengan mengisi material secara berturutturut yaitu batu pecah, pasir, semen, air, abu ampas tebu, dan abu sekam serta sika Viscocrete-10, diaduk hingga campuran homogen;

5. Pengukuran flow test dari beton segar;

6. Kemudian mortar dituang kedalam cetakan benda uji, dipadatkan dengan palu karet, lalu diratakan permukaannya menggunakan sendok semen;

7. Perawatan dilakukan ketika beton sudah mengeras, beton dikeluarkan dari cetakan kemudian direndam dalam bak perendaman selama umur beton selama 28 hari;

8. Setelah 28 hari beton dikeluarkan dari bak perendaman kemudian diletakkan di lingkungan terlindung, tidak terlindung, tertimbun, sesuai dengan kode benda uji.

Teknik pengumpulan data mencakup pengambilan sampel tanah, pengukuran sifat-sifat fisis, pembuatan benda uji, pemadatan, dan pengujian CBR (California Bearing Ratio). Penelitian ini dilakukan dengan berbagai variasi campuran aspal emulsi untuk mendapatkan gambaran tentang stabilisasi yang baik pada tanah campuran.

\subsection{Perawatan Benda Uji}

Perawatan benda uji dimulai setelah benda uji sudah mengeras. Benda uji tersebut direndam selama 28 hari di bak perendaman. Setelah 28 hari perendaman kemudian benda uji diletakkan di tiga lingkungan yang sudah direncanakan yaitu lingkungan terlindung, lingkungan terbuka, dan lingkungan tertimbun. Benda uji tertimbun ditanam di dalam tanah sedalam $\pm 1 \mathrm{~m}$. Kondisi ini dilewati benda uji selama 7 hari dan 28 hari.

Variasi jenis dan jumlah benda uji diperlihatkan pada Tabel 2.

Tabel 2. Variasi Jenis Benda Uji Berdasarkan

\begin{tabular}{|c|c|c|c|c|}
\hline \multirow{2}{*}{$\begin{array}{c}\text { Kondisi } \\
\text { Lingkunga }\end{array}$} & \multirow{2}{*}{$\begin{array}{c}\text { Persentase } \\
(\%)\end{array}$} & \multicolumn{2}{|c|}{ Umur (hari) } & \multirow{2}{*}{ Jumlah } \\
\hline & & 7 & 28 & \\
\hline \multirow{4}{*}{$\begin{array}{l}\text { Terlindung } \\
\text { (T) }\end{array}$} & $0 \%$ & T111-T113 & T121-T123 & 6 \\
\hline & $2,5 \%$ & T211-T213 & T221-Т223 & 6 \\
\hline & $5 \%$ & T311-T313 & T321-Т323 & 6 \\
\hline & $7,5 \%$ & $\mathrm{~T} 411-\mathrm{T} 413$ & $\mathrm{~T} 421-\mathrm{T} 423$ & 6 \\
\hline \multirow{4}{*}{$\begin{array}{c}\text { Tidak } \\
\text { Terlindung } \\
\text { (TT) }\end{array}$} & $0 \%$ & TT111-TT113 & TT121-TT123 & 6 \\
\hline & $2,5 \%$ & TT211-TT213 & TT221-TT223 & 6 \\
\hline & $5 \%$ & TT311-TT313 & TT321-TT323 & 6 \\
\hline & $7,5 \%$ & TT411-TT413 & TT421-TT423 & 6 \\
\hline \multirow{4}{*}{$\begin{array}{l}\text { Tertimbun } \\
\text { (TB) }\end{array}$} & $0 \%$ & TB111-TB113 & TB121-TB123 & 6 \\
\hline & $2,5 \%$ & TB211-TB213 & TB221-TB223 & 6 \\
\hline & $5 \%$ & TB311-TB313 & TB321-TB323 & 6 \\
\hline & $7,5 \%$ & TB411-TB413 & TB421-TB423 & 6 \\
\hline \multicolumn{4}{|c|}{ Total } & 72 \\
\hline
\end{tabular}
Lingkungan

\subsection{Pengujian Kuat Tarik Belah}

Pengujian kuat tarik belah dilakukan dengan cara meletakkan benda uji silinder secara horizontal dengan 
beban tekan diberikan merata arah tegak dari atas pada seluruh panjang silinder hingga kekuatan terlampaui, benda uji terbelah menjadi dua bagian. Pembacaan beban maksimum dilakukan pada saat turunnya angka pembebanan dan diikuti dengan terbelahnya benda uji. Beban yang menyebabkan benda uji terbelah merupakan data yang kemudian digunakan untuk memperoleh nilai kuat tarik belah. Besarnya kuat tarik belah beton dihitung berdasarkan Persamaan 1.

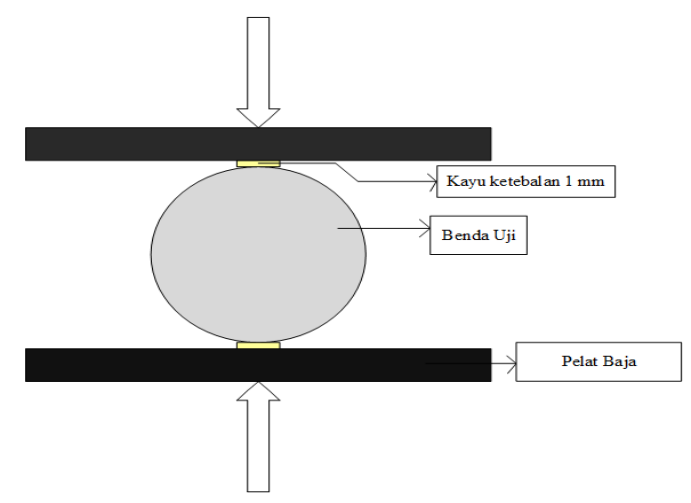

Gambar 1 Pengujian Kuat Tarik Belah

\section{Hasil dan Pembahasan}

\subsection{Hasil}

\subsubsection{Hasil Pemeriksaan Sifat Fisis Abu Ampas Tebu dan Abu Sekam Padi}

Hasil sifat fisis material abu ampas tebu dan abu sekam padi yang dilakukan di Laboratorium Konstruksi Bahan Bangunan Universitas Syiah Kuala diperlihatkan pada Tabel 3 berikut.

Tabel 3 Pemeriksaan Sifat Fisis Abu Ampas Tebu dan Abu Sekam Padi

\begin{tabular}{cccc}
\hline \multirow{2}{*}{ No } & $\begin{array}{c}\text { Pemeriksaan } \\
\text { Sifat Fisis }\end{array}$ & $\begin{array}{c}\text { Hbu Ampas } \\
\text { Tebu }\end{array}$ & $\begin{array}{c}\text { Abu Sekam } \\
\text { Padi }\end{array}$ \\
\hline 1 & Berat Volume & $1,142 \mathrm{~kg} / \mathrm{l}$ & $0,387 \mathrm{~kg} / 1$ \\
\hline 2 & $\begin{array}{c}\text { Berat Jenis } \\
\text { (SSD) }\end{array}$ & 1,776 & 1,483 \\
\hline
\end{tabular}

\subsubsection{Hasil Pemeriksaan Sifat Fisis Agregat}

Jenis agregat kasar yang digunakan adalah jenis Split, dengan ukuran butiran 6-10 mm, dan agregat halus yang digunakan jenis pasir dengan ukuran butiran 0-2 $\mathrm{mm}$. Hasil pemeriksaan agregat menunjukkan bahwa berat volume split $(6-10 \mathrm{~mm})$ dan pasir $(0-2 \mathrm{~mm})$ lebih besar dari 1,2 kg/l Mulyono[8]. Pada pemeriksaan berat jenis saturated surfaced dry (SSD) dan oven dry (OD) didapat nilai berat jenis untuk split yaitu 2,715 dan untuk pasir yaitu 2,545. Sedangkan nilai absorpsi hasil penelitian adalah 0,909 untuk split dan 0,593 untuk pasir. Nilai pemeriksaan fineness modulus didapatkan untuk split yaitu 5,843 dan untuk pasir yaitu 2,456. Dari pemeriksaan-pemeriksaan tersebut dapat diketahui bahwa campuran agregat berada di daerah tiga berdasarkan grafik campuran maksimum $10 \mathrm{~mm}$ (Mulyono). Hal ini membuat agregat yang digunakan sudah memenuhi syarat. Grafik campuran agregat dapat dilihat pada Gambar 2.

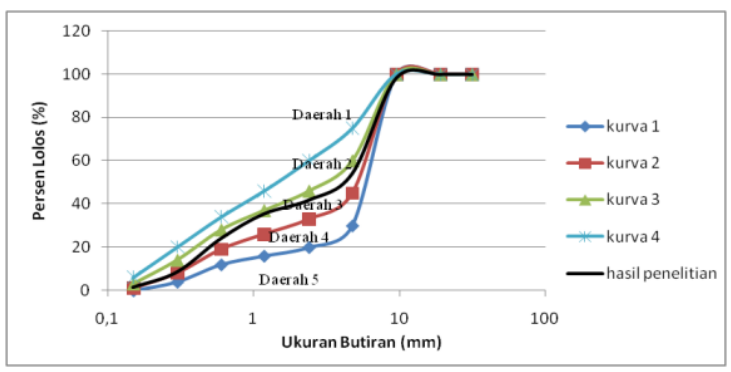

Gambar 2 Grafik Agregat Campuran Maksimum 10 mm

\subsubsection{Hasil Perencanaan Proporsi Campuran Beton}

Rancangan proporsi campuran beton direncanakan untuk beton mutu tinggi dengan kuat tekan rencana $60 \mathrm{MPa}$ dan FAS 0,3. Hasil perhitungan campuran beton mutu tinggi untuk $1 \mathrm{~m}^{3}$ menggunakan subsitusi abu ampas tebu dan abu sekam padi dengan persentasi $0 \%, 2,5 \%, 5 \%$, dan 7,5\% dapat dilihat pada Tabel 4.

Tabel 4 Rancangan Campuran Beton per $1 \mathrm{~m}^{3}$

\begin{tabular}{ccccc}
\hline \multirow{2}{*}{$\begin{array}{c}\text { Material } \\
(\mathbf{k g})\end{array}$} & \multicolumn{4}{c}{ Subsitusi Abu Ampas Tebu dan Abu Sekam Padi } \\
\cline { 2 - 5 } & $\mathbf{0 \%}$ & $\mathbf{2 , 5 \%}$ & $\mathbf{5 \%}$ & $\mathbf{7 , 5 \%}$ \\
\hline Air & 180 & 173,220 & 166,439 & 159,659 \\
\hline Semen & 600 & 570 & 540 & 510 \\
\hline Abu Apas Tebu & 0 & 2,102 & 4,205 & 6,307 \\
\hline Abu Sekam Padi & 0 & 5,296 & 11 & 15,889 \\
\hline Pasir $(0-2 \mathrm{~mm})$ & 717,824 & 730,773 & 744,738 & 758,704 \\
\hline Split (6012 mm) & 913,595 & 930,075 & 947,849 & 965,623 \\
\hline Sika Viscocrete-10 & 9 & 8,66 & 8,322 & 7,98 \\
\hline
\end{tabular}

\subsubsection{Hasil Kuat Tarik Belah Beton Mutu Tinggi}

Pengujian kuat tarik belah dilakukan setelah 7 dan 28 hari pengeksposan dengan variasi substitusi abu ampas tebu dan abu sekam padi sebesar 0\%, 2,5\%, 5\%, dan $7,5 \%$. Benda uji direndam selama 28 hari di bak perendaman, kemudian diletakkan di tiga lingkungan yang sudah ditentukan yaitu lingkungan terlindung, tidak terlindung, dan tertimbun selama 7 dan 28 hari. Sebelum dilakukan pengujian benda uji diukur dan ditimbang beratnya. Hasil pengujian kuat tarik belah bahan uji silinder dengan substitusi abu ampas tebu dan abu sekam padi sebesar $0 \%, 2,5 \%, 5 \%$, dan $7,5 \%$ pada lingkungan terlindung, tidak terlindung, dan tertimbun selama 7 dan 28 hari disajikan pada Gambar 3 dan Gambar 4

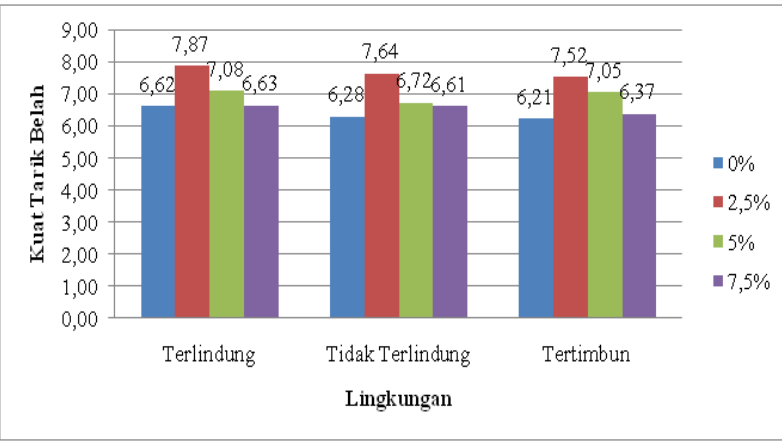

Gambar 3 Grafik Perbandingan Kuat Tarik Belah pada Lingkungan Berbeda Selama 7 Hari 


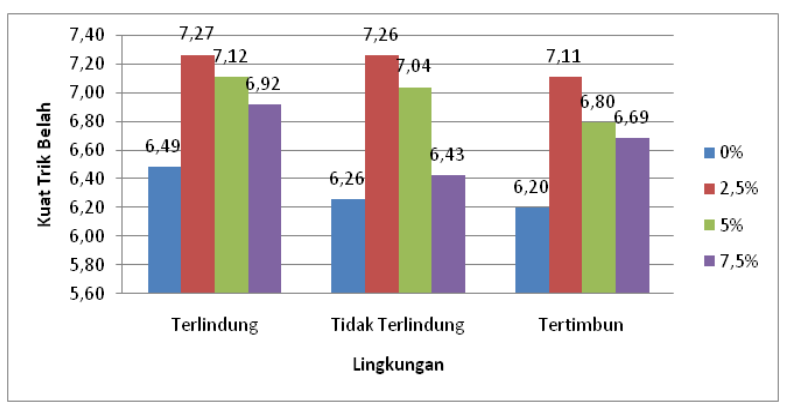

Gambar 4 Grafik Perbandingan Kuat Tarik Belah pada Lingkungan Berbeda Selama 28 Hari

\subsubsection{Analisa Varian}

Perhitungan analisa varian bertujuan untuk mengetahhui pengaruh kondisi lingkungan terhadap kuat tarik belah beton pada umur yang berbeda dan variasi yang berbeda. Hasil perhitungan analisa varian dapat dilihat pada Tabel 5 dan Tabel 6.

Tabel 5 Analisa Varian Pengaruh Substitusi Semen Terhadap Kuat Tarik Belah Beton Mutu Tinggi umur 7 Hari di Lingkungan Berbeda

\begin{tabular}{cccccc}
\hline Sumber & Jumlah & Derajat & Rata-rata & Fo & Fo Tabel \\
\cline { 5 - 6 } Varian & Kuadrat & Kebebasan & Kuadrat & & \\
\hline Lingkungan & 0,49 & 2 & 0,49 & 4,28 & 1,51 \\
\hline Persentase & 201,46 & 3 & 67,15 & 584,09 & 1,51 \\
\hline Interaksi & $-191,96$ & 6 & $-63,99$ & $-556,56$ & 1,51 \\
\hline Error & 4,14 & 24 & 0,11 & & \\
\hline Total & 14,13 & 35 & & & \\
\hline
\end{tabular}

Tabel 6 Analisa Varian Pengaruh Substitusi Semen Terhadap Kuat Tarik Belah Beton Mutu Tinggi umur 7 Hari di Lingkungan Berbeda

\begin{tabular}{cccccc}
\hline Sumber & Jumlah & Derajat & Rata-rata & Fo & Fo Tabel \\
\cline { 5 - 6 } Varian & Kuadrat & Kebebasan & Kuadrat & & \\
\hline Lingkungan & 0,41 & 2 & 0,41 & 1,76 & 1,51 \\
\hline Persentase & 204,85 & 3 & 68,28 & 289,59 & 1,51 \\
\hline Interaksi & $-200,44$ & 6 & $-66,81$ & $-283,35$ & 1,51 \\
\hline Error & 8,49 & 24 & 0,24 & & \\
\hline Total & 13,32 & 35 & & & \\
\hline
\end{tabular}

\subsection{Pembahasan}

\subsubsection{Pembahasan Kuat Tarik Belah Beton Mutu}

Tinggi terhadap Variasi Substitusi Abu Ampas

Tebu dan Abu Sekam Padi

Adapun hubungan kuat tarik belah beton mutu tinggi menggunakan substitusi $0 \%, 2,5 \%, 5 \%$, dan 7,5\% abu ampas tebu dan abu sekam padi di lingkungan terlindung, tidak terlindung, dan tertimbun selama 7 dan 28 hari dapat dilihat pada Gambar 5, Gambar 6, dan Gambar 7.

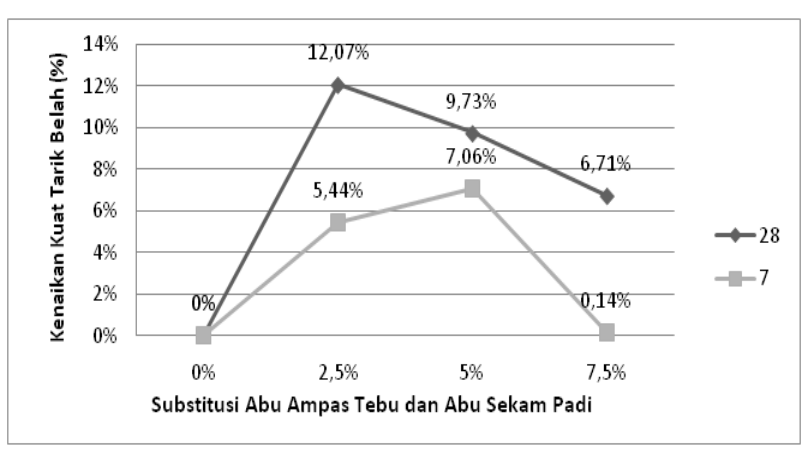

Gambar 5 Hubungan Substitusi terhadap Peningkatan Kuat Tarik Belah pada Lingkungan Terlindung

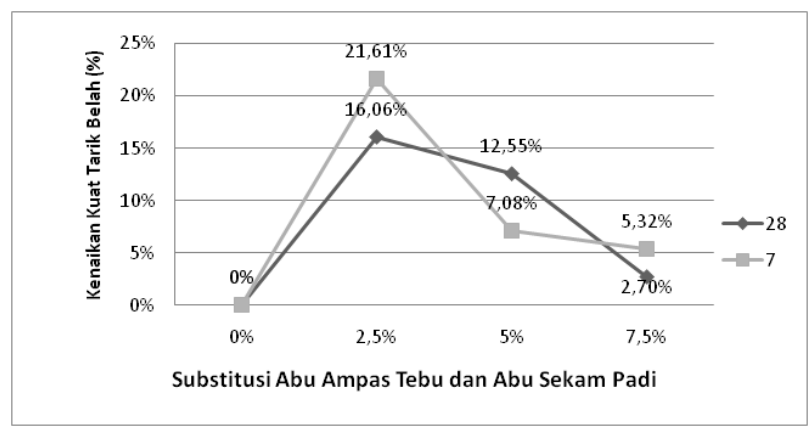

Gambar 6 Hubungan Substitusi terhadap Peningkatan Kuat Tarik Belah pada Lingkungan Tidak Terlindung

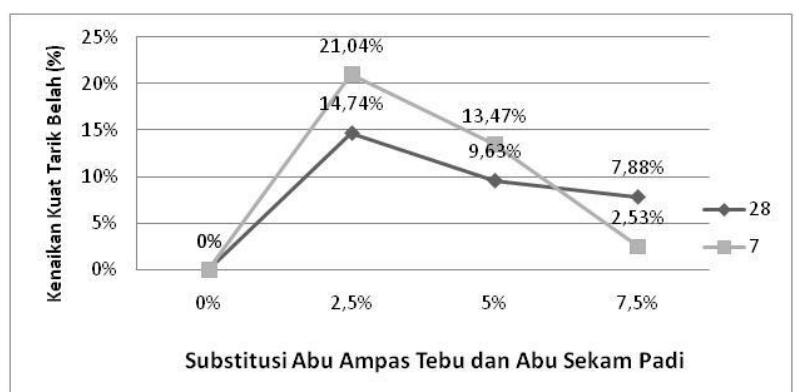

$\begin{array}{lllll}\text { Gambar } & 7 & \text { Hubungan } & \text { Substitusi terhadap }\end{array}$ Peningkatan Kuat Tarik Belah pada Lingkungan Tertimbun

Kenaikan kuat tarik belah paling signifikan terjadi pada benda uji yang diletakkan di tiga lingkungan berbeda selama 7 hari, dapat dilihat pada Gambar 5, Gambar 6, dan Gambar 7, kenaikan nilai kuat tarik belah benda uji di lingkungan berbeda selama 28 hari rata-rata lebih rendah daripada 7 hari. Hal ini dikarenakan benda uji sudah dirawat sebelumnya selama 28 hari di bak perendaman, sehingga beton sudah mencapai kekuatan maksimumnya. Penurunan kualitas beton diduga karena pengaruh sinar matahari, cuaca, juga kondisi tanah. Reaksi silika yang merupakan pozolan terhadap beton juga mempengaruhi kualitas beton, berhubung jumlah silika yang terkandung pada beton akan berbeda di tiap variasi. 


\subsubsection{Pembahasan perbandingan kuat tarik belah} terhadap kondisi lingkungan

Kenaikan kuat tarik belah beton mutu tinggi terhadap variasi lingkungan terjadi pada setiap persentase. Nilai selisih kuat tarik belah beton terhadap kondisi lingkungan yang berbeda dapat dilihat pada Gambar 8 dan Gambar 9.

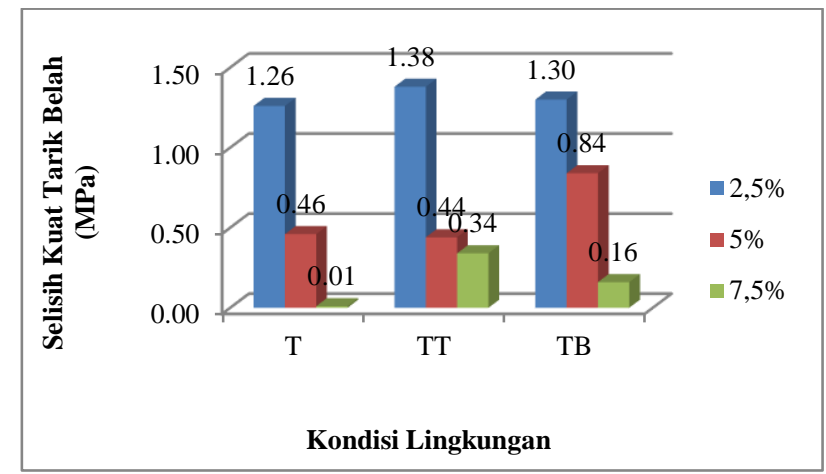

Gambar 8 Grafik kenaikan kuat tarik belah terhadap beton tanpa substitusi pada lingkungan berbeda selama 7 hari

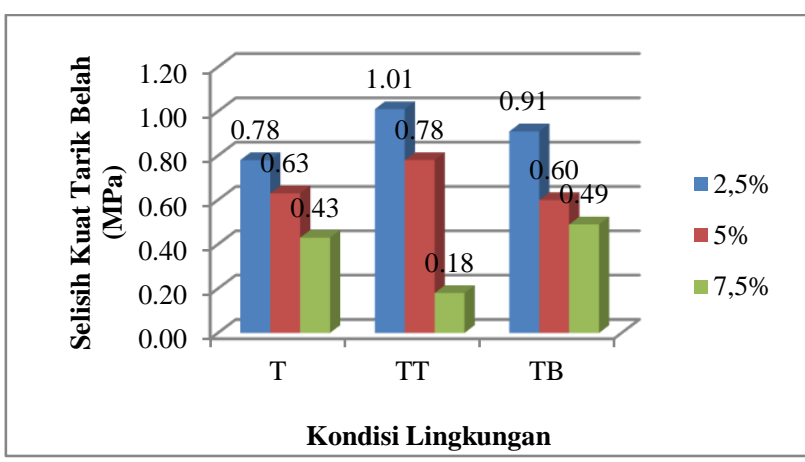

Gambar 9 Grafik kenaikan kuat tarik belah terhadap beton tanpa substitusi pada lingkungan berbeda selama 28 hari

Setelah benda uji diletekkan di lingkungan berbeda selama 7 hari, terjadi kenaikan kuat tarik belah paling optimum pada persentase $2,5 \%$ yaitu sebesar 1,26 $\mathrm{MPa}$ pada lingkungan terlindung, 1,38 $\mathrm{MPa}$ pada lingkungan tidak terlindung dan $1,30 \mathrm{MPa}$ pada lingkungan tertimbun. Sedangkan pada 28 hari, terjadi kenaikan kuat tarik belah paling optimum pada persentase 2,5\% yaitu sebesar $0,78 \mathrm{MPa}$ pada lingkungan terlindung, 10,01 MPa pada lingkungan tidak terlindung dan 0,91 MPa pada lingkungan tertimbun.

\subsubsection{Pembahasan kuat tarik belah beton mutu tinggi terhadap lingkungan terlindung}

Standar normal nilai kuat tarik belah adalah pada lingkungan terlindung, untuk itu didapat hubungan kuat tarik belah ada lingkungan tidak terlindung dan tetimbun terhadap kuat tarik belah lingkungan terlindung yang dapat dilihat pada Gambar 10 dan Gambar 11 .
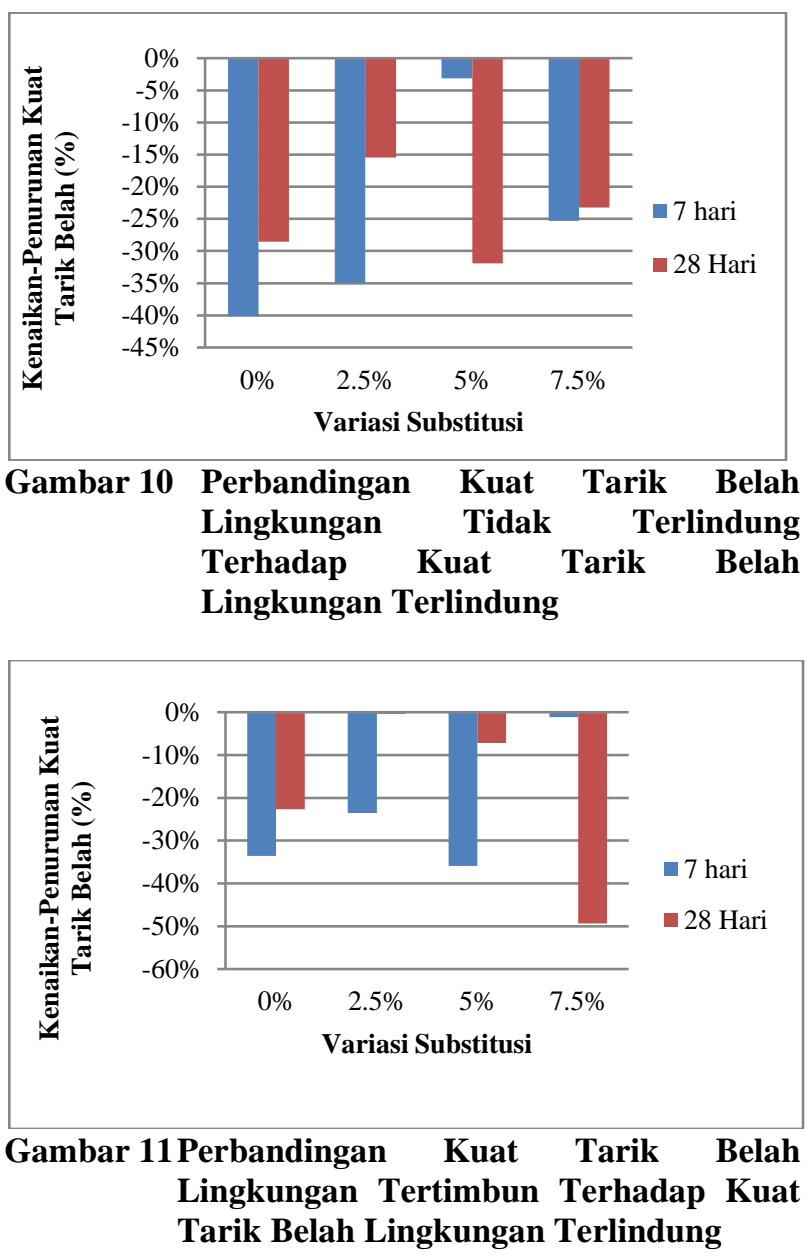

Benda uji yang diletakkan di lingkungan terbuka dan tertimbun, cenderung mengalami penurunan nilai kuat tarik belah jika dibandingkan dengan benda uji yang diletakkan di lingkungan terlindung, seperti yang apat dilihat pada Gambar 10 dan 11. Pada Gambar 10, diketahui bahwa benda uji di lingkungan tidak terlindung baik pada variasi substitusi $0 \%, 2,5 \%, 5 \%$, dan $7,5 \%$ semuanya mengalami penurunan nilai kuat tarik belah. Hal ini disebabkan dengan adanya pengaruh sinar matahari, hujan, dan angin yang mempengaruhi kualitas beton. Begitu pula pada lingkungan tertimbun seperti pada gamabr 11, nilai kuat tarik belah mengalami penurunan pada umur 7 dan 28 hari, di semua variasi substitusi. Hal ini disebabkan oleh adanya pengaruh kondisi tanah tempat dilakukannya penimbunan benda uji. Reaksi silika yang merupakan pozolan terhadap beton juga mempengaruhi kualitas beton, berhubung jumlah silika yang terkandung pada beton akan berbeda di tiap variasi.

\subsubsection{Pembahasan Analisa Varian}

Berdasarkan Tabel 5 dan Tabel 6 dapat diperoleh hasil:

1. Pada pengujian kuat tarik belah pada lingkungan berbeda selama 7 hari nilai Fo lingkungan adalah $4,28>$ Fo tabel $=1,51$. Begitu pula pada 28 hari dengan nilai Fo lingkungan adalah 1,76> Fo tabel $=1,51$. Hal ini menunjukkan bahwa kondisi lingkungan memberikan pengaruh terhadap kuat tarik belah beton. 
2. Pada pengujian kuat tarik belah pada lingkungan berbeda selama 7 hari nilai Fo persentase adalah $584,09>$ Fo tabel $=1,51$. Begitu pula pada 28 hari dengan nilai Fo lingkungan adalah 289,59 > Fo tabel $=1,51$. Hal ini menunjukkan bahwa variasi persentase memberikan pengaruh terhadap kuat tarik belah beton.

3. Pada pengujian kuat tarik belah beton mutu tinggi pada lingkungan berbeda selama 7 hari nilai Fo interaksi adalah $-556,56>$ Fo tabel $=1,51$. Begitu pula pada 28 hari dengan nilai Fo interaksi adalah $-283,35>$ Fo tabel $=1,51$. Hal ini menunjukkan bahwa interaksi antara penggunaan persentase yang berbeda tidak berpengaruh dengan kondisi lingkungan.

\section{Kesimpulan}

1. Nilai kuat tarik belah terbesar beton mutu tinggi dengan persentase substitusi semen sebesar 2,5\%, yaitu pada lingkungan terlindung, tidak terlindung, dan tertimbun selama 7 hari masing-masing sebesar 7,87 MPa, 7,64 MPa, dan 7,52 MPa.

2. Nilai kuat tarik belah terbesar beton mutu tinggi dengan persentase substitusi semen sebesar 2,5\%, yaitu pada lingkungan terlindung, tidak terlindung, dan tertimbun selama 28 hari masing-masing sebesar 7,11 MPa, 6,80 MPa, dan 6,69 MPa.

3. Terjadi peningkatan nilai kuat tarik belah pada variasi substitusi $2,5 \%$ di semua kondisi lingkungan setelah benda uji di letakkan di lingkungan berbeda selama 28 hari, yaitu pada lingkungan terlindung terjadi peningkatan sebesar $12,07 \%$ dari beton mutu tinggi normal, pada lingkungan tidak terlindung terjadi peningkatan sebesar 16,06\% dari beton mutu tinggi normal, dan pada lingkungan tertimbun terjadi peningkatan sebesar $14,74 \%$ dari beton mutu tinggi normal.

4. Berdasarkan analisa data diketahui bahwa variasi varian substitusi berpengaruh pada kuat tarik belah beton mutu tinggi dengan dicapainya hasil Fo > Fo tabel, begitu juga pada kondisi lingkungan yang juga mencapai hasil Fo > Fo tabel.

\section{Saran}

1. Diharapkan dapat menemukan bahan substitusi lain yang dapat meningkatkan mutu beton.

2. Diharapkan penelitian selanjutnya dilakukan pada beton mutu yang berbeda.

3. Penelitian selanjutnya diharapkan dapat menggunakan umur pada kondisi lingkungan yang berbeda atau variasi substitusi yang berbeda untuk menambah informasi mengenai mengenai penelitian kuat tarik belah beton mutu tinggi dengan substitusi abu ampas tebu dan abu sekam padi.

\section{Daftar Pustaka}

[1] Dharma P., 2006, Penambahan Abu Sekam Padi pada Beton dalam Mengantisipasi Kerusakan Akibat Magnesium Sulfat pada Air Laut, Jurnal Ilmiah Teknik Sipil, Vol.10, No.2, Universitas Udayana, Danpasar.
[2] Hernando F., 2009, Perencanaan Campuran Beton Mutu Tinggi dengan Penambahan Superplasticizer dan Pengaruh Penggantian Sebagian Semen dengan Fly Ash, Universitas Islam Indonesia, Yogyakarta.

[3] ASTM (American Society For Testing and Material), C. 150-07, Standard Specification For Portland Cement, International StandardsWorldwide.

[4] Maulana M., 2017, Pengaruh Penggunaan Abu Ampas Tebu dan Abu Sekam Padi Sebagai Substitusi Semen Terhadap Kuat Tarik Belah Beton Mutu Tinggi, Universitas Syiah Kuala, Banda Aceh.

[5] ASTM (American Society For Testing and Material), C. 496M-04, Standard Test Method for Splitting Tensile Strength of Cylindrial Concrete Specimens, International Standards-Worldwide.

[6] Rayyana N., 2017, Pengaruh Penggunaan Campuran Abu Ampas Tebu dan Abu Sekam Padi Sebagai Substitusi Semen Terhadap Kuat Tekan Beton Mutu Tinggi Pada Lingkungan yang Berbeda, Universitas Syiah Kuala, Banda Aceh.

[7] Hines W. W., Montgomery D. C., 1990, Probabilitas Statistik dalam Ilmu Rekayasa dan Manajemen, Edisi Kedua, Terjemahan Rudiansyah dan A. H. Manarung, UI Press, Jakarta.

[8] Mulyono N., 2004, Teknologi Beton, Penerbit Andi, Yogyakarta. 